\title{
The Vertical Distribution of Marine Macropiankton. XII. Some Observations on the Vertical Distri- bution of Calanus finmarchicus in Relation to Light Intensity.

\author{
By
}

F. S. Russell,

Naturalist at the Plymouth Laboratory.

With 3 Figures in the Text.

IN my previous reports on the vertical distribution of plankton animals off Plymouth the apparent importance of light-intensity as a major factor in determining the behaviour of some species has been repeatedly stressed. The results appeared to show that individuals of a species, when in a state in which they react towards light, will congregate in those water layers in which certain optimum light conditions are to be found. There seems now to be no doubt that at certain times in the life-history of a plankton animal the strength of light has a predominating influence so that in a study of the habits of plankton animals the light conditions must be measured as being a factor of the environment of equal importance to such factors as temperature and salinity. Now that the observation of the light conditions has been made possible through the researches of Poole and Atkins we are in a position to study this factor in research on the ecology of plankton animals.

The first contribution to this line of research has been made by Clarke (2) on the basis of observations made in the Gulf of Maine in July and August, 1931. During the same period in that year in collaboration with Dr. Atkins I made a number of observations on the vertical distribution of plankton animals off Plymouth with simultaneous measurements of light intensity beneath the sea surface. It is with some of the results of this work that the present report is concerned.

As a working hypothesis it had been assumed that for some species there is an absolute light intensity optimum, but that while this optimum may remain constant for short periods of time it changes from time to time in accordance with the various changes in development during the lifehistory of the animal and may be different for different broods.

For a preliminary test of this theory it was felt that it was better to NEW SERIES.-VOL. XIX. NO. 2. MAY, 1934. 
make a number of observations on different days than to follow an actual migration through 24 hours. If in the middle of the day on different days the animals were found to be living at depths at which they experienced similar light intensities, better proof of the theory would be obtained than by attempting to correlate the light intensity with the distribution of the animal during active migration, when such factors as the swimming speed of the animal and its speed of reaction might tend to prevent it from keeping accurately within the zone of optimum light conditions. During full daylight the animals would have had more time to congregate around the region of their true optimum.

Ideally the observations should be made either on cloudless days or on days of uniform dullness; under such conditions the animals would show best the light conditions they prefer. On days of constantly changing illumination it is doubtful whether at any one time the animals will be found accurately concentrated round the actual optimum light conditions. Unfortunately some of the days on which my observations were made were anything but ideal in this respect.

Seven series of observations were made on five days, July 21st, 22nd, and 29th, and August 5th and 12th, 1931, two observations being made on the first and last of these days respectively. The collections were made with usually six nets fished simultaneously in a horizontal direction for half an hour. Light measurements were made by Dr. Atkins at different depths immediately before or after the collecting period, and the air illuminations were observed during the time the nets were fishing. Most of the collections were made at a position 2 miles east of the Eddystone Lighthouse, the depth being about 50 metres.

\section{Collecting Methods.}

In my previous researches I had fished only with one net, a series of catches being made consecutively at different depths. Under such conditions the period of time between the first and last hauls of a series of six collections must necessarily be considerable. If accurate comparison was to be made with light conditions it was therefore essential that the six nets should be fished simultaneously. It was necessary that the depth at which each net was fishing should be known, and as closing mechanisms were not used it was essential that the nets could be attached to and detached from the towing wire as quickly as possible.

The nets used were coarse silk nets of the international pattern (silk No. 3 ; 58 strands to the inch; diameter of opening $50 \mathrm{~cm}$.). The silk was however attached directly by a calico band to the ring without the half-inch meshing used in the international design $(8$, p. 7$)$ : the ring was made of brass $\frac{3}{8}$-inch diameter (weight $c a .2 \mathrm{lb} .1 \frac{1}{2} \mathrm{oz}$.). 
If six nets be attached at intervals to a wire with a single weight at its end the wire will be considerably curved when the nets are fishing somewhat after the style of $\mathrm{A}$ in Figure 1, and it would be difficult to estimate the depth of any one net. For any fishing method it would certainly be extremely complicated, if indeed possible, to predict by calculation the actual depths at which the nets would fish. A practical attempt was made to overcome this difficulty by using the Admiralty depth-recorder as the end weight and by attaching a metre below each net a lead weight whose weight in water was the same as that of the depth-recorder in water (Fig. 1, B).

The accuracy of this method was tested by taking a successive series of hauls and interchanging the depth-recorder with each of the lead weights

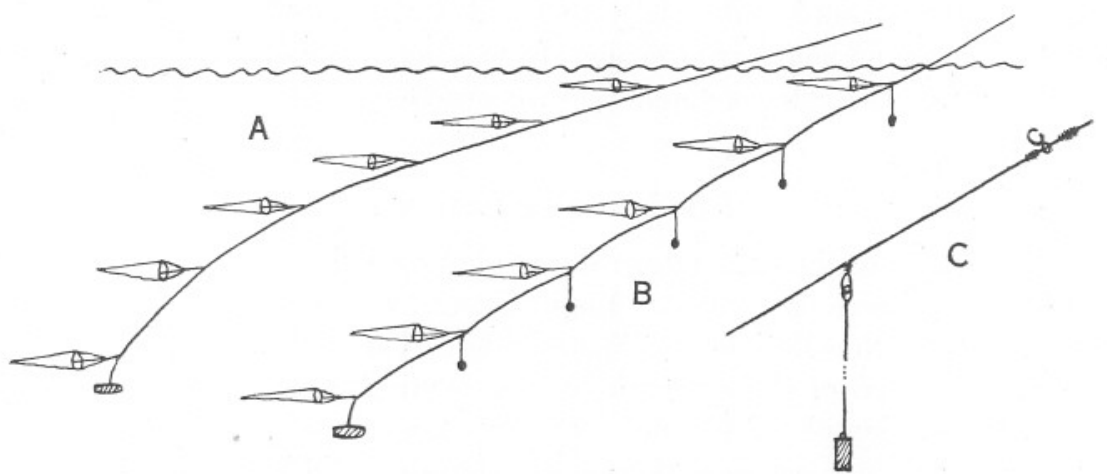

FIG. 1.-Fishing methods. A, with single weight at end of towing-wire; B, with weights by each net on towing-wire; C, method of attachment for nets and weights.

in turn. It was found that on this occasion the average depths of each of five nets were as follows :-

Surface, $7 \mathrm{~m}$., $14.4 \mathrm{~m}$., $22.6 \mathrm{~m}$, and $29.5 \mathrm{~m}$.: the depth intervals between each net were thus $7,7 \cdot 4,8 \cdot 2$, and $6 \cdot 9 \mathrm{~m}$. These results were sufficiently close to enable one to assume that the nets in the other series of observations fished at approximately equal intervals of depth. In order to ensure that each series was hauled in exactly the same way and at the same speed a declinometer was hung on the wire as described in $\mathbf{8}$, page 9 . The angle aimed at was $30^{\circ}$, and by varying the speed of the ship's engine the pendulum was kept oscillating slowly about this angle. By observation of objects drifting past the ship's side it was found that with an average angle of $28.6^{\circ}$ the speed averaged $1 \cdot 2$ knots : at an average angle of $31.2^{\circ}$ it was $1.03 \mathrm{knots}$, and at $25.4^{\circ}$ it was 1.42 knots : the extreme variation was thus probably between 1 and 1.5 knots.

In order to ensure rapidity of work the gear was attached in the following manner. The nets were fixed to the wire $\left(\frac{3}{4}\right.$-inch circumference 
flexible steel) by signal halyard swivel clips : one half of each swivel was attached to a rope from the tow-net bridles; and the other halves were threaded on to the towing wire and fixed at intervals of 15 metres by stoppings of twine rove through the wire (Fig. 1, C). One metre below each swivel a small bight was made in the wire for the attachment of the lead weights. Each lead weight ( $c a .9 \frac{1}{4} \mathrm{lb}$. in air) had a length of rope with a slip-hook at its end. When shooting, a net was held by one man and a lead by another; as each bight and swivel attachment passed over the ship's side the net and weight were quickly hitched on without stopping the wire from coming off the winch; similarly each net and lead could be quickly detached as the wire came in. The errors due to the nets fishing in layers above their correct depths were thus reduced to a minimum. Each net was numbered serially to avoid confusion on deck; when all the nets were on board after fishing the washing down of the silk and preservation of the catches could thus be proceeded with carefully and at leisure.

\section{The Light Conditions.}

The details of the light measurements have already been published by Atkins and Poole (1, p. 141). Measurements were obtained with a gasfilled potassium cell under a diffusing filter. This cell was sensitive only to the blue end of the spectrum with a maximum sensitivity probably near a wave-length of $440 \mathrm{~m} \mu$. Observations were made immediately before or after the net collections so that figures could be obtained for the coefficients of absorption of the water at different depths. During the hauls a photometer was used on the roof of the ship's deck-house to measure the air illumination; a number of measurements were made while the nets were fishing and a mean value was taken. From these mean values and the knowledge of the coefficients of absorption of the water the submarine illumination was calculated for the depths at which the nets were fishing. The details of these illuminations are given in Table I.

On July 21st, 1931, immediately after the first series of collections, further measurements were made on the penetration of other wavelengths of light, using a thin film caesium on silver vacuum cell, with red, yellow, green, and blue filters under opal. On August 12th measurements were also made of the penetration of the near ultra-violet light with a Burt sodium vacuum cell and a $10 \mathrm{~mm}$. Corex red-purple filter.

Full details of the general weather and lighting conditions on the days on which collections were made are given in the log at the end of this report. At the same time records were obtained of the illumination for some hours prior to the times of collecting by the photo-electric continuous light recorder on the roof of the Plymouth Laboratory. Although 
these results will not be a faithful reproduction of the light conditions ten miles out to sea where the collections were made, they nevertheless serve as a good guide to the average illuminations obtaining when our observations were made. The results are reproduced in Figure 2. It can be seen that on no day were the light conditions ideally constant; on the other hand at the times that collections were made the light was evidently not varying as badly as it might have done. Examination of Figure 2 shows that on July 21st at the times when Series I and II were made the light conditions had become tolerably constant which is in agreement with the observations made on the ship and given in the log. On July 22 nd the conditions had been fairly constant, increasing steadily until a short time before the period of collecting when they became more varied. On July 29 th for an hour before the collections were made the illumination had been increasing and decreasing on a very smooth curve, but became more varied at the time of collecting. On August 5th both prior to and during the time of collecting there were a few short periods of increased intensity but on the whole the light had been varying constantly within small limits. On August 12th conditions had been varying to about the same extent as on August 5th but had been consistently low.

Of the five days July 21st was the only bright day; the other four days, and particularly the last three were dull and overcast.

Examination of Figure 2, page 145 in the paper by Atkins and Poole (1) shows that for the five days (Series 55, 60, 61, 67 and 75 loc. cit.) the transparency of the water had been much the same, and that the transparency varied very little at different depths except on August 12th (Series 75) when the water became appreciably clearer in the deeper layers. Also "in Series 61 (July 29th) the zone of less transparent water, $\mu=$ $0 \cdot 173$ is found at $5-10 \mathrm{~m}$., instead of $0-5 \mathrm{~m} . "$ (1, p. 148). From these results I have calculated the depths at which the following intensities would, at the time of collecting, have been found on each day, viz. 80, 60, $40,20,10,5,4,3,2,1$, and 0.5 thousands of metre-candles. These have been plotted on Figure 3, drawing the curves of equal illuminations for the seven series of observations.

As a result of further photo-electric measurements on July 21st and August 12th we can get an approximate picture also of the penetration of light of different wave-lengths beneath the sea surface. Examination of Figure 5, p. 153 in 1, shows that for the wave-lengths $580 \mathrm{~m} \mu$ to $440 \mathrm{~m} \mu$, yellow $\rightarrow$ green $\rightarrow$ blue, there is comparatively little difference in the amount of absorption at any rate down to 30 metres. But light at the red end of the spectrum $660 \mathrm{~m} \mu$ to $760 \mathrm{~m} \mu$ is much more rapidly absorbed and has become reduced to 1 per cent of the illumination immediately below the surface before a depth of 10 metres has been reached. The violet and near ultra-violet rays, to $360 \mathrm{~m} \mu$, however, penetrate slightly further than 
TABLE I.

Vertical Illuminations, V, in Thousands of Metre Candles, at the Depths (d), in Metres, at which the Six Nets were Fishing.

The depth of the water was about $50 \mathrm{~m}$., and position 2 miles East of Eddystone Lighthouse. $r=$ illumination on deckhouse roof.

\begin{tabular}{|c|c|c|c|c|c|c|c|c|c|c|c|c|c|c|}
\hline \multirow{4}{*}{$\begin{array}{l}\text { Date } \\
\text { 1931, July } \\
\text { G.M.T. } \\
\text { Series }\end{array}$} & \multirow{3}{*}{\multicolumn{2}{|c|}{$\begin{array}{l}\text { 21st. } \\
2.24-2.54 \text { p.m. } \\
\text { I }\end{array}$}} & \multirow{3}{*}{\multicolumn{2}{|c|}{$\begin{array}{l}\text { 21st. } \\
\text { 5.54-6.24 p.m. } \\
\text { II* }\end{array}$}} & \multirow{3}{*}{\multicolumn{2}{|c|}{$\begin{array}{l}\text { 22nd. } \\
11.11-11.41 \text { a.m. } \\
\text { III }\end{array}$}} & \multirow{3}{*}{\multicolumn{2}{|c|}{$\begin{array}{l}29 \text { th. } \\
11.39 \text { a.m.- } \\
12.9 \text { p.m. } \\
\text { IV }\end{array}$}} & \multirow{3}{*}{\multicolumn{2}{|c|}{$\begin{array}{c}\text { Aug. 5th. } \\
\text { 11.19-11.39 a.m. } \\
V\end{array}$}} & \multirow{3}{*}{\multicolumn{2}{|c|}{$\begin{array}{l}\text { 12th. } \\
10.55-11.25 \text { a.m. } \\
\text { VI }\end{array}$}} & \multirow{3}{*}{\multicolumn{2}{|c|}{$\begin{array}{c}\text { 12th. } \\
3.7-3.32 \text { p.m. } \\
\text { VII* }\end{array}$}} \\
\hline & & & & & & & & & & & & & & \\
\hline & & & & & & & & & & & & & & \\
\hline & $d$ & V & $d$ & V & $d$ & V & $d$ & V & $d$ & V & $d$ & V & $d$ & V \\
\hline In air & $r$ & $88 \cdot 6$ & $r$ & $27 \cdot 1$ & $r$ & $91 \cdot 5$ & $r$ & $50 \cdot 0$ & $r$ & $26 \cdot 9$ & $r$ & $35 \cdot 4$ & $r$ & $45 \cdot 8$ \\
\hline 1. & 0.5 & $80 \cdot 8$ & 0.5 & $24 \cdot 7$ & 0.5 & $72 \cdot 8$ & 0.5 & $45 \cdot 4$ & 0.5 & $22 \cdot 0$ & 0.5 & $24 \cdot 4$ & 0.5 & $31 \cdot 6$ \\
\hline 2. & $7 \cdot 2$ & $34 \cdot 4$ & $7 \cdot 9$ & $9 \cdot 36$ & $8 \cdot 1$ & $19 \cdot 7$ & $7 \cdot 1$ & $16 \cdot 4$ & $7 \cdot 2$ & $7 \cdot 05$ & $7 \cdot 5$ & $11 \cdot 5$ & $7 \cdot 0$ & $15 \cdot 7$ \\
\hline 3. & $14 \cdot 3$ & $13 \cdot 2$ & $15 \cdot 7$ & $3 \cdot 32$ & $16 \cdot 1$ & $6 \cdot 63$ & $14 \cdot 4$ & $6 \cdot 55$ & $14 \cdot 3$ & $2 \cdot 42$ & $14 \cdot 9$ & $4 \cdot 34$ & $13 \cdot 8$ & $6 \cdot 65$ \\
\hline 4. & $21 \cdot 4$ & $5 \cdot 18$ & $23 \cdot 5$ & $1 \cdot 24$ & $24 \cdot 1$ & $2 \cdot 78$ & $21 \cdot 7$ & $2 \cdot 22$ & $21 \cdot 4$ & $0 \cdot 88$ & $22 \cdot 3$ & $2 \cdot 07$ & $20 \cdot 6$ & $3 \cdot 11$ \\
\hline 5. & $28 \cdot 5$ & $2 \cdot 39$ & $31 \cdot 3$ & $0 \cdot 54$ & $32 \cdot 1$ & $1 \cdot 39$ & $29 \cdot 0$ & $1 \cdot 29$ & $28 \cdot 5$ & $0 \cdot 47$ & $29 \cdot 7$ & 1.08 & $27 \cdot 4$ & $1 \cdot 66$ \\
\hline 6. & $35 \cdot 6$ & $1 \cdot 03$ & $39 \cdot 1$ & $0 \cdot 16$ & $40 \cdot 1$ & $0 \cdot 43$ & $36 \cdot 3$ & 0.53 & - & - & $37 \cdot 1$ & 0.58 & $34 \cdot 2$ & 0.91 \\
\hline
\end{tabular}


do the red rays and are not reduced to 1 per cent until after 15 metres have been reached.

It is interesting that as regards the shorter anti-rachitic ultra-violet M.C. $\times 10^{3}$

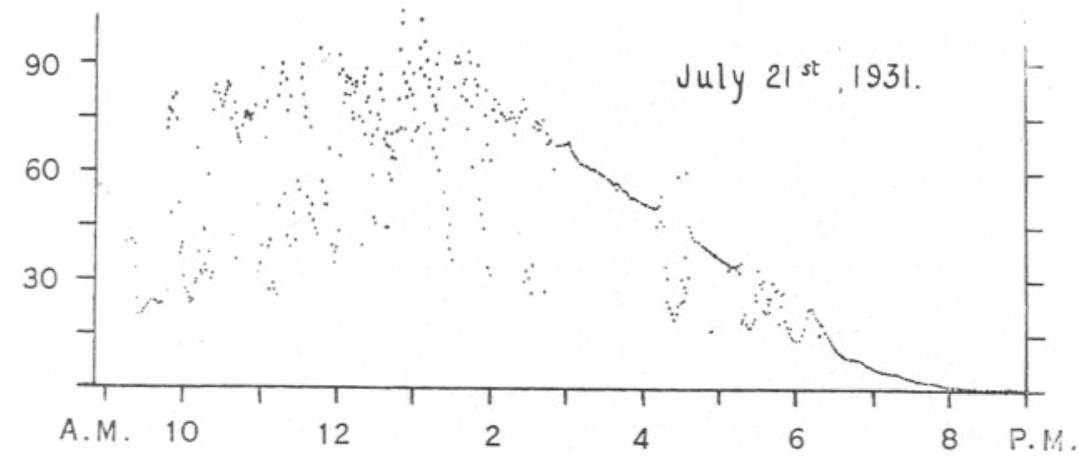

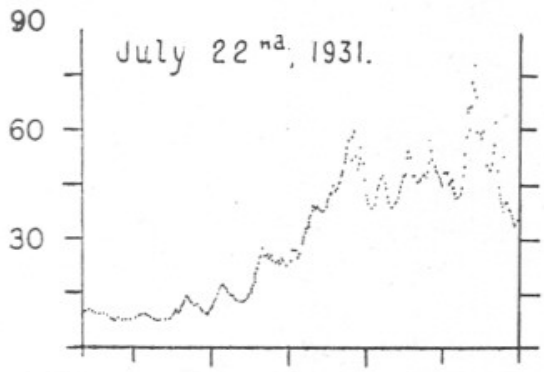

A.M. 8

12

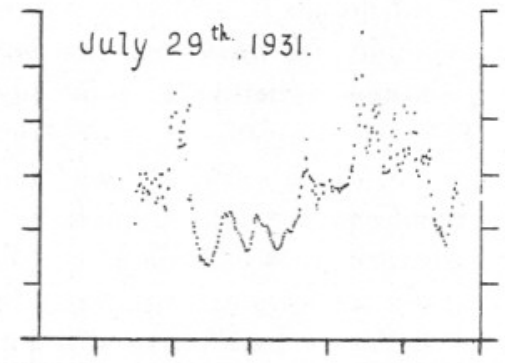

A. M. 10

12

P. M.
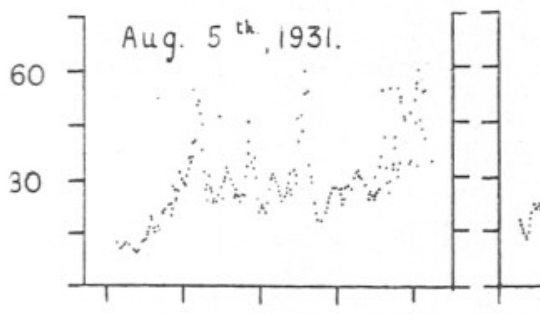

Aug. $12^{\text {th }}, 1931$.

A.M. 10

12

A.M. 10

12

2 P.M. 4

FIG. 2.-Records of light intensity obtained on roof of Plymouth Laboratory with vacuum photo-electric cell and thread-recorder, on July 2lst, 22nd, and 29th, and August 5th and 12th, 1931. (By courtesy of Dr. W. R. G. Atkins.)

rays Atkins and Poole write, "Hulbert's coefficients have been used to show that even in the clearest ocean waters the anti-rachitic portion of the spectrum is reduced to 1 per cent of its subsurface value at $1 \cdot 1$ to $2.2 \mathrm{~m}$., according to wave-length, and to 0.001 per cent at from 2.9 to 
$5.5 \mathrm{~m}$." They suggest, however, that " it also seems possible that, though anti-rachitic action is but feeble at wave-lengths longer than $313 \mathrm{~m} \mu$, yet owing to their better penetration those somewhat longer than the limit given may be more effective in sea-water."

\section{The Vertical Distribution of Calanus finmarchicus in Relation to Light Conditions.}

In working up the material of the collections all the species were counted. It has, however, been shown previously that in order to elucidate the principles underlying the behaviour of the animals it is useless to work on a mixed population; the population of any one species needs to be further analysed into the sexes and stages of development occurring therein. This further analysis has only been done for the copepod, Calanus finmarchicus, and in this paper I deal only with adult males and females. Owing also to the possibility of differences in behaviour shown between different broods it is necessary to make a further analysis of the Calanus by making size measurements as these may indicate differences in the populations occurring from day to day.

The general results of these observations on adult Calanus are given in Figure 3, which shows the percentage vertical distribution of the females and males on the days in question. The actual numbers of Calanus in the catches are given in Table II on page 583 ; it can be seen that the numbers are fully large enough to be significant. On the diagram in Figure 3 are also given the lines of equal illumination in thousands of metre-candles calculated as explained previously (see page 573). Underneath the depth distribution diagrams for each sex are given the median lengths $\left(Q_{2}\right)$ and upper and lower quartiles $\left(Q_{3}\right.$ and $\left.Q_{1}\right)$ being the lengths between which 50 per cent of the population lay on each day. The length measurements are the total length of the body to the end of the caudal furca but excluding the furcal setæ. A number of both sexes were measured from every catch (Tables III and IV, pp. 583 and 584). In estimating the median length the numbers measured at each depth in a series were added together. Gardiner has shown that there may be a slight difference in the depth distribution between individuals of different sizes in Stage V, the larger individuals in a population being deeper (3, p. 590); see also Marshall (4, p. 123). Insufficient numbers were measured on this occasion to show significant differences in size-composition of the catches from different depths, but it was evident that such difference if it occurred would not have been of the order of the differences that will be referred to later between one whole population and another in July and August.

An examination of Figure 3 shows that during the four observations in July (Series I-IV) the majority of the female Calanus were near the 
surface and living in the very high light intensities of 20,000 metrecandles and more: below 10,000 metre-candles the remaining Calanus appear to be evenly distributed. In August (Series V to VII) there is a definite change in the vertical distribution, the female Calanus now avoiding light intensities of 20,000 metre-candles and over. This change is very noticeable and at first sight would have been regarded as a change in the behaviour of the animal. A study of the length measurements shows, however, that instead of there being a change in behaviour there has been a change in population. We are quite definitely dealing with a different population in August from that we had in July. In July the median lengths of the female Calanus in the Series I to IV were $3 \cdot 186$, $3 \cdot 169,3 \cdot 170$, and $3 \cdot 141 \mathrm{~mm}$. respectively, while in August for Series V to VII these lengths were $3 \cdot 068,3 \cdot 000$, and $3 \cdot 013 \mathrm{~mm}$. The change in population receives further confirmation from the appearance in August catches of numbers of early stages of Calanus, whereas in July the catches consisted almost purely of adults. In August we have possibly therefore a new brood of adults which have just grown up, or one consisting perhaps of the smaller individuals that may be produced towards the end of a breeding period (Marshall, 4, p. 122).* This difference in behaviour between different populations is in keeping with previous observations ( $\%$, p. 438$)$ which led to the suggestion that the different broods were physiologically distinct and showed differences in their behaviour towards light intensity. It emphasises at once the danger of attempting to make conclusions on the effects of the environment on an animal without a certain knowledge of the population under examination. Analysis of the vertical distribution results of the female Calanus on July 29th and August 5th, 1931, would certainly have led to wrong conclusions if length measurements had not been made at the same time. If we turn now to the results for the male Calanus we notice a similar change in depth distribution coincident with a change of population. The male Calanus were living deeper in the water than the females and tended very definitely to avoid those high light intensities in which the females were living. In July (Series I to IV) the male Calanus definitely avoided intensities of 40,000 metre-candles and over, but below about 20,000 metre-candles they were rather evenly distributed in the water though there are indications in Series II and IV that they tried to keep above intensities of 500 metre-candles and less. In August (Series V to VII) the majority of the males were deeper in the water than in July and were now avoiding intensities as low as 10,000 metre-candles. Here again we find length differences between individuals

* A number of female Calanus were stained and examined for state of maturity. In the limited number examined no significant difference could be found in the proportions of the different degrees of maturity occurring in the July and August populations. I am very grateful to Miss S. M. Marshall and Dr. A. G. Nicholls for examining these specimens for me. 
SERIES I

II III

III

IV

21. VIII. 31 .

2I. VII. 31 .

22.VIII. 31.

29. VII. 31 .

V

VI

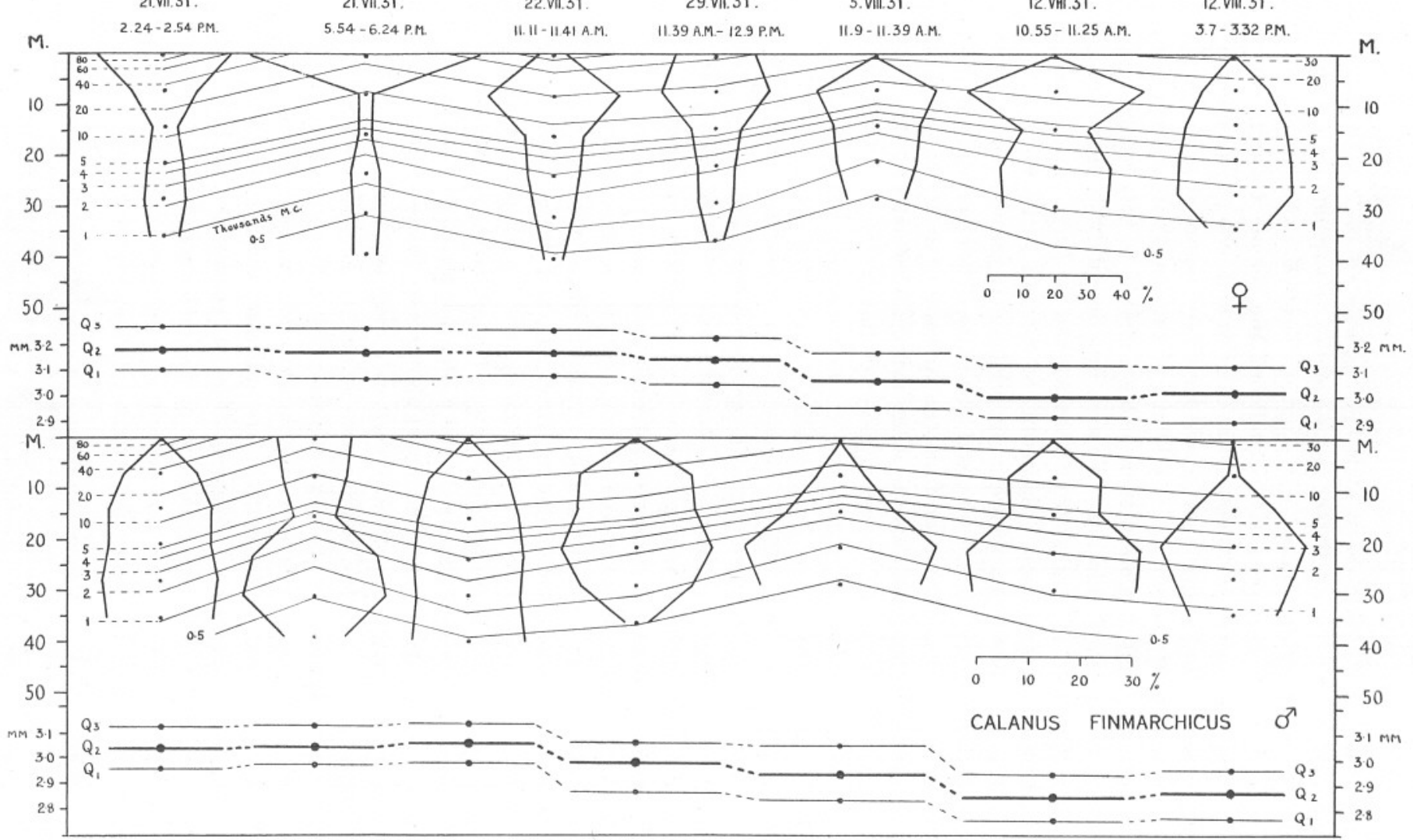

Fig. 3.-Percentage vertical distribution of adult Calanus finmarchicus; females above, males below. The black spots indicate the depths at which the nets were fishing. For each day are plotted the light intensities beneath the surface and these points are joined to form the isointensity lines of $80,60,40,20,10,5,4,3,2,1$, and 0.5 thousands of metre-candles. Below each diagram is given the medium length $\left(Q_{2}\right)$ and upper and lower quartiles $\left(Q_{3}\right.$ and $\left.Q_{1}\right)$ of the Calanus. (The diagrams for the males Series II, III, and IV are slightly to the left of those for the females.) 
of the July and August populations. While in Series I to III in July the median lengths were $3 \cdot 034,3 \cdot 043$, and $3.060 \mathrm{~mm}$., in August, Series VI and VII, they were 2.837 and $2.873 \mathrm{~mm}$. In Series IV and V, however, at the end of July and beginning of August they occupied an intermediate position of 2.987 and $2.943 \mathrm{~mm}$. respectively, which may have indicated a mixing of the two populations.

This tendency for the males to avoid the bright intensities that the females can endure is in keeping with previous results for this region ( $\%$, p. 442). The very even distribution assumed below the upper limit at times appears also to be somewhat characteristic of the males and seems to imply a less sharply graded sensitivity to light intensities between the upper and lower limits than is shown by the females. This type of distribution for the males has recently been shown also by Nicholls (5, p. 146) to occur in the Clyde Sea area, where at different times during the day this difference in behaviour between male and female is clearly indicated. It is interesting that in the observations made by Nicholls the upper limit of intensity avoided by the male Calanus would appear to be as high as that avoided by females on the same day.

On the whole the present results appear to support the light optimum theory referred to above (p. 569). The preference of the July individuals for higher intensities than the August individuals is consistent. Very close agreement is shown between the distribution of the females and the light conditions in the two Series of observations made on July 21st (Series I and II). Between 2.24 and 2.54 p.m. the threshold intensity for stimulation of upward movement seems to have been somewhere between 20,000 and 10,000 m.c. By 5.54 to 6.24 p.m. the female Calanus have crowded very much more towards the surface and the threshold illumination still appears to lie at about 20,000 m.c. The males also show agreement in that while at 2.24 to $2.54 \mathrm{p} . \mathrm{m}$. the upper limiting intensity was about 60,000 m.c., at 5.54 to 6.24 p.m., when intensities of 40,000 m.c. and over could no longer be experienced, the male Calanus had extended their distribution to the surface.

It is difficult, however, from these observations to decide on the optimum conditions except within very wide limits. The female Calanus, for instance, in Series III and IV would appear to have a slightly lower optimum than those in Series I and II. It is interesting, however, that if these four observations be arranged in the order of the time of day at which they were taken the Calanus are found to have slightly increasing optima, which might point to increasing adaptation on the part of the Calanus throughout the day. No such increase is, however, shown in the two series taken on August 12th (Series VI and VII). We must wait for further observations to be made before we can decide the cause of these discrepancies or whether indeed they may not be false impressions brought 
about by the inability of the animals to keep accurately to their optima during rapid fluctuations in light intensity.

These collections were made at a time of year when Calanus is living nearer the surface than earlier in the year. The present observations confirm the results of two previous years (6 and $\mathbf{7})$, although the August population was living deeper than might have been expected. It is possible, however, that they are more recently moulted from Stage V than those occurring in the July collections and have not yet developed to the age at which they desire bright light. It should also be mentioned that the upper water layers were considerably warmer on August 12th than on July $22 \mathrm{nd}$, the temperatures at $15 \mathrm{~m}$. being $15 \cdot 0^{\circ} \mathrm{C}$. and $12 \cdot 4^{\circ} \mathrm{C}$., respectively (see Log, p. 582).

It is a great pleasure for me to thank Dr. W. R. G. Atkins for his willing co-operation and assistance in this work, and for his kind permission to reproduce the light measurements in Figure 2. My thanks are also due to Captain Lord and the Crew of s.s. Salpa for their great help while the collections were being made, and to my wife for the assistance she gave me in helping to sort and count the collections.

\section{SUMMARY.}

1. Observations are given on the vertical distribution of adult Calanus finmarchicus in the daytime off Plymouth in July and August, 1931, as a result of collections made simultaneously with the photo-electric measurement of submarine illumination.

2. A series of nets, usually six, was towed simultaneously in such a manner that the depth of each net was known approximately.

3. The female Calanus in July preferred higher intensities of light than did the females in August; this change was coincident with a change in the Calanus population as shown by size measurements. A similar change in distribution and in population was shown by the males.

4. The females in July were living in intensities of 20,000 m.c. and more ; but those in August were avoiding such high intensities. The males in July avoided intensities of 40,000 m.c. and over, while in August their upper limit was about 10,000 m.c.

\section{REFERENCES.}

1. Atkins, W. R. G., and Poole, H. H. The Photo-electric Measurement of the Penetration of Light of various Wave-lengths into the Sea and the Physiological Bearing of the Results. Phil. Trans. Roy. Soc., London, Ser. B, Vol. 222, 1933, pp. 129-164. 
2. Clarke, George L. Diurnal Migrations of Plankton in the Gulf of Maine and its Correlation with changes in Submarine Irradiation. (Abstract.) Cons. Perm. Int. Explor. Mer., Rapp. Proc. Verb., Vol. LXXXV, 3ème Part, Appendix, 1933, pp. 52-59.

3. Gardiner, A. C. Vertical Distribution in Calanus finmarchicus. Journ. Mar. Biol. Assoc., N.S., Vol. XVIII, No. 2, 1933, pp. 575610 .

4. Marshald, S. M. On the Biology of Calanus finmarchicus. II. Seasonal Variations in the Size of Calanus finmarchicus in the Clyde Sea-Area. Ibid., Vol. XIX, No. 1, 1933, pp. 111-138.

5. Nicholds, A. G. On the Biology of Calanus finmarchicus. III. Vertical Distribution and Diurnal Migration in the Clyde Sea-Area. Ibid., Vol. XIX, No. 1, 1933, pp. 139-164.

6. Russell, F. S. The Vertical Distribution of Marine Macroplankton. IV. The Apparent Importance of Light Intensity as a Controlling Factor in the Behaviour of Certain Species in the Plymouth Area. Ibid., Vol. XIV, No. 2, 1926, pp. 415-440.

7. The Vertical Distribution of Marine Macroplankton. VII. Observations on the Behaviour of Calanus finmarchicus. Ibid., Vol. XV, No. 2, 1928, pp. 429-454.

8. Russell, F. S., and Colman, J. S. The Zooplankton. I. Gear, Methods and Station Lists. Scientific Reports. Great Barrier Reef Expedition, 1928-29, British Museum (Nat. Hist.), Vol. II, No. 2, 1931, pp. 5-35.

July 21 st, 1931.

LoG.

From 12.15 p.m. until 1.25 p.m. there had been high clouds and blue sky, but the sun was partially obscured : from then until 1.55 p.m. the sun shone brightly in a clear sky, with cumulus coming up on S.W. horizon, and wind freshening slightly from the west. At 1.55 p.m. a very thin sheet of high cloud passed over the sun but barely obscured it. The sea surface was calm, with slight swell and lop.

SERIEs I. 2 miles East of Eddystone.

Six nets fished together on 75 metres of wire : nets 15 metres apart. Depth recorder and 5 weights $\left(c a .9 \frac{1}{4} \mathrm{lb}\right.$. in air) each one metre below nets. Nets= coarse silk international without front meshing.

The sky was quite cloudless for the whole haul, almost over the whole sky except the horizon.

$$
2.24-2.54 \text { p.m. }
$$

Average depths of nets. Surface, $7 \cdot 2,14 \cdot 3,21 \cdot 4,28 \cdot 5$, and $35 \cdot 6 \mathrm{~m}$. Nets took 4 min. 35 secs. shooting; and 4 min. 6 secs. hauling.

3.45 p.m. Cloudless sky. 5.23 p.m. Almost cloudless sky except for a little wispy cirrus. 5.38 p.m. Sun going behind a cloud. 
Series II. By this time we had drifted to near L4, half-way between Breakwater and Eddystone.

$$
5.54 \text { p.m. }-6.24 \text { p.m. }
$$

Six nets as in Series I, fishing at average depths of surface, $7 \cdot 9,15 \cdot 7,23 \cdot 5$, $31 \cdot 3$, and $39 \cdot 1 \mathrm{~m}$.

At 5.58 the sun came out clear again.

Nets took 3 min. 35 secs. shooting; and 2 min. 38 secs. hauling.

Sun was shining all the time after 5.58 p.m.

July $22 n d, 1931$.

8 a.m. Very dull and patches of fog. 10.45 a.m. Clearing and sun shining enough to throw shadows. Had been dull up to now. 11 a.m. Sun shining fairly fully through thin sheet of low cloud.

Series III. 2 miles East of Eddystone : sea choppy. Six nets fished as in previous series.

$$
11.11 \text { a.m.-11.41 a.m. }
$$

Nets fished at average depths of surface, $8 \cdot 1,16 \cdot 1,24 \cdot 1,32 \cdot 1$, and $40 \cdot 1 \mathrm{~m}$.

Nets took $2 \mathrm{~min}$. 37 secs. shooting; and $1 \mathrm{~min} .59$ secs. hauling.

1 p.m. Secchi disc $9 \mathrm{~m}$. on windward side : $8 \mathrm{~m}$. on leeward side. Temperatures of sea : surface, $14 \cdot 5^{\circ} \mathrm{C}$. ; $5 \mathrm{~m} ., 13^{\circ} \mathrm{C}$. ; $10 \mathrm{~m} ., 12 \cdot 8^{\circ} \mathrm{C}$; $15 \mathrm{~m} ., 12 \cdot 4^{\circ} \mathrm{C}$. ; $25 \mathrm{~m} ., 12 \cdot 2^{\circ} \mathrm{C}$.

July 29th, 1931.

S.W. wind : slight lop. It had been dull with the sun covered all morning. Cloud-sheet was of uneven thickness, so that the light was variable.

SERIES IV. 2 miles East of Eddystone.

Six nets fished as previously.

$$
11.39 \text { a.m.-12.9 p.m. }
$$

Nets fished at average depths of surface, $7 \cdot 1,14 \cdot 4,21 \cdot 7,29 \cdot 0$, and $36 \cdot 3 \mathrm{~m}$. Nets took 2 min. 23 secs. shooting and $2 \mathrm{~min}$. 18 secs. hauling.

Secchi disc: $7 \mathrm{~m}$. on weather side; $8 \mathrm{~m}$. on leeward side. The sun was covered the whole time but the cloud-sheet was of very uneven thickness.

August 5th, 1931.

It had been dull with thick low clouds all morning; at 9.55 the sun was trying to show through a slight break in the clouds. Calm. S.E. breeze.

In shooting lost one net so started again with five.

Series V. 2 miles East of Eddystone.

$$
\text { 11.19-11.39 a.m. }
$$

Nets fished at average depths of surface, $7 \cdot 1,14 \cdot 4,21 \cdot 7$, and $29 \mathrm{~m}$. Nets took 2 min. 5 secs shooting; and 1 min. 46 secs. hauling.

Secchi disc : $10 \mathrm{~m}$. on weather side; $12 \mathrm{~m}$. on leeward side.

August 12th, 1931.

Sea calm at first; clouds all over sky; low nimbo-cumulus type at about $1500 \mathrm{ft}$.

Series VI. 2 miles East of Eddystone. 


$$
10.55 \text { a.m. }-11.25 \text { a.m. }
$$

Nets fished at average depths of surface, $7 \cdot 5,14 \cdot 9,22 \cdot 3,29 \cdot 7$, and $37 \cdot 1 \mathrm{~m}$. Bottom net touched bottom while shooting. Nets took 3 min. 8 secs. shooting; and $2 \mathrm{~min} .50$ secs. hauling.

Secchi disc : $12 \frac{1}{2} \mathrm{~m}$. on weather side; $15 \mathrm{~m}$. on leeward side.

1.45 p.m. Temperatures of sea. Surface $15 \cdot 1^{\circ}$ C. ; 5 m., $15 \cdot 1^{\circ}$ C. ; $10 \mathrm{~m}$., $15 \cdot 04^{\circ} \mathrm{C} . ; 15 \mathrm{~m} ., 15 \cdot 0^{\circ} \mathrm{C}$. ; $20 \mathrm{~m} ., 13 \cdot 7^{\circ} \mathrm{C}$. ; $30 \mathrm{~m} ., 13 \cdot 4^{\circ} \mathrm{C}$.

2.30 p.m. Sun shining through clouds.

Series VII. 2 miles East of Eddystone.

$$
3.7-3.32 \text { p.m. }
$$

Nets fished at average depths of surface, $7 \cdot 0,13 \cdot 8,20 \cdot 6,27 \cdot 4$, and $34 \cdot 2 \mathrm{~m}$. Nets took 2 min. 49 secs. shooting; and 2 min. 30 secs. hauling.

3.25 p.m. Secchi disc $15 \mathrm{~m}$. on leeward side.

Haul ended about 4 miles E.N.E. of Eddystone.

\section{TABLE II.}

Numbers of Calanus Females and Males in each Catch.

\begin{tabular}{|c|c|c|c|c|c|c|c|c|c|c|c|}
\hline \multicolumn{4}{|c|}{$\begin{array}{c}\text { SERIES I. } \\
\text { July } 21 \text { st, } 1931 .\end{array}$} & \multicolumn{5}{|c|}{ SERIES II. } & & \multicolumn{2}{|c|}{ SERIES III. } \\
\hline D. & 웅 & o & & D. & & & $\hat{0}$ & & . & 우 & $\hat{0}$ \\
\hline$S$. & 22,726 & 18 & & $S$. & 70, & & 6,088 & & & 980 & - \\
\hline $7 \cdot 2$ & 11,669 & 5,32 & & $7 \cdot 9$ & & & 5,108 & & 1 & 4,233 & 2,568 \\
\hline $14 \cdot 3$ & 4,822 & 7,36 & & $15 \cdot 7$ & & & 3,377 & & & 1,952 & 3,355 \\
\hline $21 \cdot 4$ & 6,384 & 7,31 & & $23 \cdot 5$ & & & 10,221 & & & 1,674 & 3,648 \\
\hline $28 \cdot 5$ & 7,420 & 8,28 & & $31 \cdot 3$ & & & 11,520 & & & 1,373 & 3,432 \\
\hline $35 \cdot 6$ & 5,038 & 7,56 & & $39 \cdot 1$ & & & 4,814 & & & 690 & 3,698 \\
\hline & $\begin{array}{r}\text { Series } \\
\text { July } 29 \text { th }\end{array}$ & $\begin{array}{l}\text { IV. } \\
h, 1931 .\end{array}$ & & $\begin{array}{l}\text { Series } \\
\text { Aug. 5th, }\end{array}$ & $\begin{array}{l}\text { V. } \\
1931 .\end{array}$ & & $\begin{array}{r}\text { SERI } \\
\text { Aug. } 12\end{array}$ & $\begin{array}{l}\text { s VI. } \\
\text { h, } 1931 .\end{array}$ & & $\begin{array}{l}\text { Series } \\
\text { ug. } 12 \text { th }\end{array}$ & $\begin{array}{l}\text { VII. } \\
1931\end{array}$ \\
\hline D. & 웅 & $\hat{\sigma}$ & D. & 우 & $0^{x}$ & D. & o & $\hat{\sigma}$ & D. & 우 & \\
\hline$S$. & 5,010 & 53 & $S$. & 7 & - & s. & 26 & 1 & S. & 127 & \\
\hline $7 \cdot 1$ & 6,592 & 1,071 & $\gamma \cdot 1$ & 1,215 & 100 & $7 \cdot 5$ & 8,664 & 1,655 & 7 & 2,179 & \\
\hline $14 \cdot 4$ & 3,290 & 1,128 & $14 \cdot 3$ & 854 & 214 & $14 \cdot 9$ & 3,300 & 1,620 & $13 \cdot 8$ & 3,270 & 1,3 \\
\hline $21 \cdot 7$ & 2,401 & 1,449 & $21 \cdot 4$ & 801 & 378 & $22 \cdot 3$ & 5,478 & 3,087 & $20 \cdot 6$ & 3,697 & \\
\hline $29 \cdot 0$ & 2,164 & 1,047 & 28.5 & 579 & 322 & $29 \cdot 7$ & 5,170 & 2,902 & $27 \cdot 4$ & 3,834 & \\
\hline $36 \cdot 3$ & 1,118 & 221 & & & & & & & $34 \cdot 2$ & 1,825 & 1,4 \\
\hline
\end{tabular}
$\mathrm{D}$, average depth of each haul. S, surface.

TABLE III.

Lengths of Calanus in Millimetres as Median $\left(Q_{2}\right)$, and Upper

\begin{tabular}{|c|c|c|c|c|c|c|c|c|}
\hline & & & $Q_{1}$ & $Q_{2}$ & $Q_{3}$ & $Q_{1}$ & $Q_{2}$ & $\mathrm{Q}_{3}$ \\
\hline July & 21st. & Ser. & $3 \cdot 102$ & $3 \cdot 186$ & $3 \cdot 275$ & 2.955 & $3 \cdot 034$ & $3 \cdot 119$ \\
\hline ," & 2lst. & II & $3 \cdot 068$ & $3 \cdot 169$ & $3 \cdot 266$ & $\cdot 2 \cdot 973$ & $3 \cdot 043$ & $3 \cdot 125$ \\
\hline , & 22nd. & III & $3 \cdot 079$ & $3 \cdot 170$ & $3 \cdot 259$ & $2 \cdot 984$ & $3 \cdot 060$ & $3 \cdot 136$ \\
\hline & 29th. & IV & $3 \cdot 045$ & $3 \cdot 141$ & $3 \cdot 227$ & $2 \cdot 875$ & 2.987 & $3 \cdot 066$ \\
\hline Aug. & 5th. & V & $2 \cdot 958$ & $3 \cdot 068$ & $3 \cdot 171$ & $2 \cdot 840$ & $2 \cdot 943$ & $3 \cdot 055$ \\
\hline , & 12th. & VI & $2 \cdot 921$ & $3 \cdot 000$ & $3 \cdot 127$ & $2 \cdot 768$ & $2 \cdot 837$ & $2 \cdot 943$ \\
\hline , & 12th. & VII & $2 \cdot 899$ & $3 \cdot 013$ & $3 \cdot 117$ & $2 \cdot 776$ & $2 \cdot 873$ & $2 \cdot 96$ \\
\hline
\end{tabular}
$\left(Q_{3}\right)$ and Lower $\left(Q_{1}\right)$ Quartiles. 
TABLE IV.

Measurements of Total Lengths of Calanus in Mullimetres.

\begin{tabular}{|c|c|c|c|c|c|c|c|c|c|c|c|c|c|c|c|}
\hline & & & & EMALI & & & & & & & MaLes. & & & & \\
\hline & 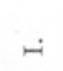 & घં & 当 & 辛 & $>$ & $\dot{5}$ & $\dot{ }$ & - & $\exists$ & $\exists$ & $\geqq$ & 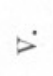 & $\dot{5}$ & $\stackrel{\vec{g}}{\lessgtr}$ & \\
\hline & $\frac{\dot{0}}{\text { ה }}$ & $\frac{\dot{\Delta}}{\Delta}$ & 总 & 㕝 & 䆛 & 苞 & 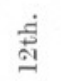 & $\frac{\dot{\Delta}}{\vec{a}}$ & $\dot{a}$ & ส્ป & 菾 & 范 & 泀 & 袁 & \\
\hline & $\frac{\overrightarrow{3}}{3}$ & $\therefore$ & $\therefore$ & 2 & $\stackrel{90}{\vec{y}}$ & $\therefore$ & $\therefore$ & $\frac{B}{\Xi}$ & : & $=$ & $\therefore$ & $\ddot{y}^{\dot{0}}$ & $\therefore$ & $\therefore$ & \\
\hline $\begin{array}{l}\text { Mм. } \\
2 \cdot 53\end{array}$ & - & - & - & - & - & 1 & - & - & - & - & - & - & - & - & : \\
\hline $2 \cdot 585$ & - & - & - & - & - & 1 & - & - & - & - & 1 & 1 & 2 & 3 & 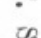 \\
\hline $2 \cdot 64$ & 1 & 1 & - & 1 & - & 2 & - & - & . - & - & - & 2 & 5 & 2 & 9 \\
\hline $2 \cdot 695$ & - & - & 1 & - & 2 & 5 & 2 & - & 1 & 2 & - & 1 & 4 & 5 & $\not 0$ \\
\hline $2 \cdot 75$ & - & - & 1 & 2 & 1 & 6 & 13 & 6 & 1 & 1 & 3 & 5 & 13 & 13 & 용 \\
\hline $2 \cdot 805$ & 2 & 2 & 2 & 6 & 7 & 12 & 17 & 6 & 6 & 9 & 7 & . 6 & 19 & 23 & 政 \\
\hline $2 \cdot 86$ & 5 & 7 & 4 & 12 & 20 & 24 & 33 & 13 & 7 & 8 & 15 & 10 & 18 & 16 & 罂 \\
\hline $2 \cdot 915$ & 9 & 9 & - & 11 & 23 & 30 & 38 & 29 & 15 & 16 & 11 & 11 & 22 & 23 & " \\
\hline $2 \cdot 97$ & 11 & 16 & 8 & 25 & 27 & 36 & $40^{\circ}$ & 28 & 21 & 25 & 14 & 13 & 14 & 18 & \\
\hline $3 \cdot 025$ & 29 & 15 & 19 & 34 & 37 & 55 & 52 & 62 & 45 & 48 & 26 & 11 & 10 & 15 & \\
\hline 3.08 & 34 & 34 & 18 & 56 & 40 & 50 & 48 & 47 & 36 & 60 & 16 & 7 & 4 & 8 & \\
\hline $3 \cdot 135$ & 61 & 39 & 31 & 67 & 41 & 38 & - & 53 & 36 & 56 & 13 & 5 & 6 & 4 & \\
\hline $3 \cdot 19$ & 85 & 50 & 34 & 83 & 37 & 35 & 27 & 34 & 27 & 31 & 8 & 9 & 2 & 3 & \\
\hline $3 \cdot 245$ & 71 & 41 & 33 & 56 & 33 & 16 & 22 & 15 & 11 & 22 & 2 & 1 & - & 1 & \\
\hline $3 \cdot 30$ & 70 & 42 & 29 & 47 & 11 & 16 & 18 & 8 & 5 & 12 & - & 1 & - & - & \\
\hline $3 \cdot 355$ & 41 & 27 & 19 & 27 & 10 & 6 & 5 & 2 & 2 & 1 & 2 & 1 & - & - & \\
\hline $3 \cdot 41$ & 25 & 9 & 6 & 7 & 4 & 3 & 1 & - & 1 & 1 & 1 & - & - & - & \\
\hline $3 \cdot 465$ & 9 & 7 & 4 & 6 & 1 & 1 & 2 & - & - & - & - & - & - & - & \\
\hline $3 \cdot 52$ & 6 & 4 & - & 5 & - & 1 & - & - & - & - & - & - & - & - & \\
\hline $3 \cdot 575$ & - & 3 & 1 & - & 1 & - & - & - & - & - & - & - & - & - & \\
\hline $3 \cdot 63$ & 2 & - & - & - & - & - & - & - & - & - & - & - & - & - & \\
\hline Totals & 461 & 306 & 210 & 445 & 295 & 338 & 366 & 303 & 214 & 292 & 119 & 84 & 119 & 134 & \\
\hline
\end{tabular}

